\title{
Characteristics of the fruits of two uvaia populations grown in Salesópolis, SP, Brazil
}

\author{
Aline Priscilla Gomes da Silva ${ }^{1}$ *Tatiane de Oliveira Tokairin ${ }^{1}$, \\ Severino Matias de Alencar ${ }^{2}$, Angelo Pedro Jacomino ${ }^{1}$
}

\begin{abstract}
Uvaia (Eugenia pyriformis Cambess) is a fruit tree native to the Atlantic Forest and that features peculiar aroma and flavor. Although this fruit is highly popular locally, its commercial farming is virtually nonexistent. In addition, limited studies on this fruit have been conducted. Therefore, the present study aimed to investigate the physical, chemical, and functional characteristics of two uvaia fruit populations grown in Salesópolis, SP, Brazil, in order to determine their potential for being consumed both in natura and processed. Uvaia fruits were evaluated as for skin color, whole fruit weight, longitudinal and transversal diameters, seed percentage, pulp yield, pulp firmness, $\mathrm{pH}$, total soluble solids (TSS), total titratable acidity (TTA), TSS/TTA ratio, total soluble sugars, soluble and total pectins, total carotenoids, yellow flavonoids, total phenolic compounds, ascorbic acid, and in vitro antioxidant capacity (DPPH and ORAC assays). The total mineral content was also determined. Comparison among the two populations revealed that uvaia fruits showed significantly different firmness values, large fruits showing suitable characteristics for the fresh fruit market. However, small fruits were sweeter and richer in antioxidants, allowing the consumption of both natural and processed fruits. Thus, this native fruit denotes an important source of nutrients and bioactive compounds, especially iron.

Index Terms: Eugenia pyriformis C.; Mineral and chemical characterizations; Antioxidant capacity; Phenolic compounds; Post-harvest quality.

\section{Características dos frutos de duas populações de uvaias cultivadas no município de Salesópolis-SP}

Corresponding author: jacomino@usp.br Received: Janeiro 03, 2017. Accepted : October 02, 2017.

Copyright: All the contents of this journal, except where otherwise noted, is licensed under a Creative Commons Attribution License.

\section{(cc) $\mathrm{EY}$}

\begin{abstract}
Resumo - A uvaia (Eugenia pyriformis Cambess) é um fruto nativo da Mata Atlântica que apresenta características de aroma e sabor bastante peculiares. Embora seja apreciado por populações locais, o cultivo comercial é praticamente inexistente, assim como os trabalhos de pesquisa. Em vista disso, este trabalho teve como objetivo caracterizar frutos de duas populações de uvaia cultivadas em Salesópolis, SP, com relação aos aspectos físicos, químicos e funcionais, com vistas a determinar o potencial para consumo in natura e/ou para processamento. Os frutos de duas populações de uvaia (frutos grandes e frutos pequenos) foram colhidos manualmente, quando atingiram o completo amadurecimento. Foram avaliados quanto à coloração da casca, peso do fruto inteiro, diâmetros longitudinal e transversal, porcentagem de sementes, rendimento em polpa, firmeza da polpa, $\mathrm{pH}$, teor de sólidos solúveis totais (SST), acidez titulável total (ATT), relação SST/ATT, açúcares solúveis totais, pectinas solúvel e total, carotenoides totais, flavonoides amarelos, compostos fenólicos totais, ácido ascórbico e capacidade antioxidante (DPPH e ORAC). Os teores de minerais totais ( $\mathrm{Fe}, \mathrm{Mn}, \mathrm{Cu}, \mathrm{Zn}, \mathrm{P}, \mathrm{K}, \mathrm{Ca}$ e $\mathrm{Mg}$ ) também foram determinados. Quando comparadas as duas populações, pode-se observar que as uvaias apresentaram diferenças expressivas na firmeza, sendo que os frutos do tipo grande apresentaram características vantajosas para a comercialização in natura. No entanto, os frutos do tipo pequeno mostraram-se mais doces e mais ricos em compostos antioxidantes, o que valoriza seu consumo nas formas in natura e processada. Portanto, esta fruta nativa constitui uma importante fonte de nutrientes e de compostos bioativos, com destaque para o Fe.
\end{abstract}

Termos para Indexação: Eugenia pyriformis C.; Caraterização química e mineral; Capacidade antioxidante, Compostos fenólicos, Qualidade pós-colheita.

\footnotetext{
${ }^{1}$ University of São Paulo, "Luiz de Queiroz" College of Agriculture, Crop Science Departament, Postharvest Laboratory of Horti-cultural Products, Piracicaba, SP, Av. Pádua Dias 11, CEP 13418-900. E-mail addresses: alinepgsilva@gmail.com, tatianetokairin@hotmail.com; jacomino@usp.br;

${ }^{2}$ University of São Paulo, "Luiz de Queiroz" College of Agriculture, Department of Agri-Food Industry, Food and Nutrition, Piracicaba, SP, Av. Pádua Dias, 11, CEP 13418-900.E-mail: smalencar@usp.br.
} 
Brazilian territory presents highly diverse biomes, among which the Atlantic Forest may be highlighted for covering an area of 1,315,460 $\mathrm{km}^{2}$ as well as encompassing 17 states. Nowadays, only $8.5 \%$ of the original $100+$ ha forests remain (SOS MATA ATLÂNTICA, 2016). This biome stands out as one of the most damaged by the anthropological action. On the other hand, it presents a great diversity of native species.

Uvaia (Eugenia pyriformis Cambess) is a fruit tree native to the Atlantic Forest and that belongs to the Myrtaceae family. Uvaia fruits present pleasant aroma and flavor and are highly variable in color - which ranges from yellow to orange -, size, shape, and firmness.

The physical, chemical, and biological characterizations of fruits has been arousing great interest of the scientific community, as these denote important tools for the understanding of their nutritional and biological values, as well as for the future human consumption. These characterizations therefore stand out as important early-stage instruments for the knowledge of the genetic material, aiming at its further multiplication.

According to Sartori et al. (2010), uvaia fruits have economic potential for both in natura and processed consumptions. However, it is still little exploited, so minor information concerning their characteristics are available. In this context, this study aimed to characterize uvaia fruits from two populations grown in Salesópolis, SP, Brazil in relation to their physical and chemical aspects and antioxidant capacity, as well as to evaluate the potential of each fruit group for in natura and/or processed consumptions.

Both of the investigated uvaia populations were grown in Salesópolis, SP, Brazil and comprised seven, 7 years-old plants of each type. The plants, which are originated from seeds, were screened by the grower as large or small fruits. Approximately 100 fruits of each type were manually harvested as soon as they reached complete ripening (November 2014) based on the outer peel color. Then, the fruits were carefully transferred to the Postharvest Laboratory of Horticultural Products (LPV-ESALQ/USP) in Piracicaba, SP, Brazil, where they were again selected for the absence of defects in order to obtain uniform batches.

Initially, 30 fruits from each population were distributed in 3 repetitions for physical analyses, each fruit being evaluated as for: a) skin color: on a Minolta ${ }^{\circledR}$ colorimeter, model CR-300, through two readings at equidistant points within the equatorial region of each whole fruit, the results being expressed as luminosity $\left(\mathrm{L}^{*}\right)$, hue angle ( ${ }^{\circ}$ hue), and chromaticity $\left.(\mathrm{C}) ; \mathrm{b}\right)$ whole fruit weight: by weighing on an analytical balance, the results being expressed as grams (g); c) longitudinal (LD) and transverse diameters (TD): measured with a digital caliper, the results being expressed as centimeter $(\mathrm{cm})$; d) seed percentage: obtained dividing the number of seeds by the whole fruit weight and multiplying by 100 ; e) pulp yield: calculated as the difference between the whole fruit weight and the seed-free pulp weight, being multiplied by 100 to be expressed as percentage; f) firmness: measured by the applanation procedure described by Calbo and Nery (1995), the results being expressed as $\mathrm{gf}^{-2}$.

Concerning the chemical analyses, the pulp resulting from 50 fruits was homogenized and submitted, in triplicates, to the following analyses: a) $\mathrm{pH}$, total soluble solid (TSS) content, and total titratable acidity (TTA): measured according with AOAC (2012) and expressed as ${ }^{\circ}$ Brix (TSS) and percentage of citric acid (TTA); b) TSS/TTA ratio: obtained by the relationship between TSS content and TTA values; c) total soluble sugars: determined in accordance with Dubois et al. (1956) and expressed as $g$ of glucose $100 \mathrm{~g}^{-1} ; \mathrm{d}$ ) soluble and total pectins: extracted according with McCready and McComb (1952) and quantified through the Bitter and Muir (1962) technique, the results being expressed as $\%$ galacturonic acid $100 \mathrm{~g}^{-1}$. Pulp samples were also frozen in liquid $\mathrm{N}_{2}$ immediately after extraction, upon collection, and stored at $-80{ }^{\circ} \mathrm{C}$ before being evaluated for the contents of total carotenoids (LICHTENTHALER, 1987), yellow flavonoids (FRANCIS, 1982), and phenolic compounds (WOISKY; SALATINO, 1998). The ascorbic acid content was quantified by titrating the samples with 2,6-dichlorophenolindophenol sodium solution, according with Strohecker and Henning (1967), the results being expressed as mg $100 \mathrm{~g}^{-1}$. Finally, antioxidant capacity was determined via both DPPH free radical scavenging (TIVERON et al., 2012) and ORAC (MELO et al., 2015) methods.

The total mineral (Fe, Mn, $\mathrm{Cu}, \mathrm{Zn}, \mathrm{P}, \mathrm{K}, \mathrm{Ca}, \mathrm{Mg}$ ) contents were determined in accordance with Malavolta et al. (1997) through inductively coupled plasma - atomic emission spectrometry (ICP-OES). The results were expressed as $\mathrm{mg} \mathrm{kg}^{-1}$ of fresh weight.

According to the grower, two uvaia types were identified in Salesópolis, SP, Brazil, namely: large and small fruits. Both are typified by the yellow-orange color $\left(\mathrm{L}^{*}=65.64 \pm 0.89 ;{ }^{\circ} \mathrm{h}=71.61 \pm 1.86\right)$, which is characteristic of such species (SCALON et al., 2004). However, large uvaia fruits presented a less intense color (47.71) than their small counterparts (53.63), as indicated by chromaticity values (Table 1). Currently, native tropical fruits have been attracting consumer because of desirable characteristics such as intense color, freshness, and taste (LIMA et al., 2016).

In addition to appearance, other characteristics (Table 1) ought to be taken into account for both in natura and processed consumption. The mean weights of the two fruit populations are different $(8.25$ to $22 \mathrm{~g}$ ). Larger uvaia fruits $(\mathrm{LD}=3.08 \mathrm{~cm}$; $\mathrm{TD}=3.92 \mathrm{~cm})$ led to higher pulp yield (94.47\%) and lower seed percentage (5.53\%), which is very attractive to the consumers. Although small 
uvaia fruits presented a pulp yield higher than $80 \%$, value which is considered suitable by Sartori et al. (2010), showed a higher seed percentage per fruit, making them less desirable for commercial applications than their larger analogues. The number of seeds may be related to the size of some fruits. This physiological aspect arises from the action of gibberellin, a hormone whose biosynthesis takes place in seeds and which acts directly on cell expansion and, as a result, on fruit growth.

Both uvaia types had a quasi-round shape $(0.82 \pm 0.05)$, indicating the homogeneity of such variable. Small fruits were stronger $\left(151.62 \mathrm{gf} \mathrm{cm}^{-2}\right)$ than large fruits (81.98 $\mathrm{gf} \mathrm{cm}^{-2}$ ) (Table 1), which may be attributed to the higher percentage of seeds.

The average $\mathrm{pH}$ and total titratable acidity of uvaia fruits of both types were 2.99 and 1.66, respectively. Large fruits presented a TSS content of $7.75^{\circ}$ Brix, whereas small fruits had $10.50^{\circ}$ Brix (Table 1), the latter resulting in a higher TSS/TTA ratio and suggesting a more pleasant flavor. The TSS values for both uvaia types obtained here were higher than those obtained by Zillo et al. (2013) and Oliveira et al. (2010). The same was observed for the TSS/ TTA ratio (RUFINO et al., 2009). It is worth mentioning that, although the TSS/TTA ratio values are low, they are higher than those of camu-camu (2.48) and close to those of acerola (5.21) and passion fruit (4.74) (RUFINO et al., 2010; SANTOS et al., 2016).

The total soluble sugar contents ranged from 4.41 (large fruits) to $5.61 \mathrm{~g}$ glucose $100 \mathrm{~g}^{-1}$ (small fruits) (Table 1), which correlate well with the TSS values found. The soluble and total pectin contents were 0.17-0.18 and $0.95 \%$ galacturonic acid $100 \mathrm{~g}^{-1}$ pulp, respectively. Together with soluble solids and $\mathrm{pH}$, pectins play an extremely important role in fruit texture, structure, and preservation, denoting the main factor taken into account by the agribusiness (especially for jelly manufacturing), besides contributing to the taste and attractiveness of processed foods (GARRIDO et al., 2015).

The uvaia fruits studied here presented average total carotenoid contents equal to $23.17 \mu \mathrm{g} \mathrm{g}^{-1}$ (Table 2). These compounds are not only pigments responsible for the color of several fruits, as uvaia, but also known to possess remarkable anti-inflammatory and antioxidant properties, which in turn are associated with the reduction of chronicdegenerative diseases such as cancer and cardiovascular diseases (KAULMANN; BOHN, 2014).

On the other hand, small fruits were distinguished by presenting, respectively, 1.2 and 1.4 times greater contents of total phenolic compounds and yellow flavonoids than large uvaia fruits (Table 2). These results corroborate that uvaia presents intermediate levels of phenolic compounds according to the classification proposed by Rufino et al. (2010). These levels are close to those of cupuaçu (510 mg GAE $100 \mathrm{~g} \mathrm{~g}^{-1}$ ) and higher than those found in blackberry fruits (300 mg GAE $100 \mathrm{~g}^{-1}$ )
(SOETHE et al., 2016).

Large and small uvaia fruits presented similar

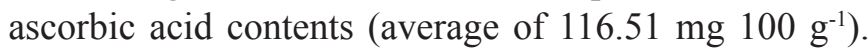
One may state that these fruits denote good sources of

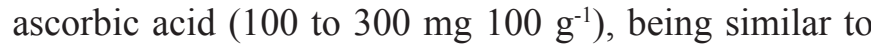
strawberry, guava, and pineapple, but greater than orange, lemon, and papaya (CAVALINI et al., 2015; REIS et al., 2015). Concerning the antioxidant capacity, the ORAC and DPPH assays led to average values of 15.45 and 17.31 mmol Trolox $100 \mathrm{~g}^{-1}$ lyophilized pulp, respectively. The obtained levels were higher than those found in blackberry fruits of the cultivars 'Tupy' and 'Guarani' (SOETHE et al., 2016) as well as in kiwi fruits grown either in organic or conventional systems $(0.62$ and $0.51 \mathrm{mmol}$ Trolox 100 $\mathrm{g}^{-1}$, respectively) (D'EVOLI et al., 2013). These results demonstrate the intermediate antioxidant capacity of uvaia fruits.

The whole uvaia fruit (peel + pulp) has been shown to be an important source of mineral elements (Table 3), which play several vital roles in synergy with vitamins, enzymes, hormones, and other nutritional co-factors in order to regulate thousands of biological functions of the human body (HAMZA et al., 2014; PEREIRA et al., 2014). These data suggest that potassium (K) contents were greater that those of the other minerals, followed by phosphorus $(\mathrm{P})$, calcium $(\mathrm{Ca})$, and magnesium $(\mathrm{Mg})$.

The potassium levels found in $100 \mathrm{~g}$ of this fruit $(99.15 \mathrm{mg})$ were similar to those identified in watermelon (104 mg $\left.100 \mathrm{~g}^{-1}\right)$, higher than that found in apple (75 mg $\left.100 \mathrm{~g} \mathrm{~g}^{-1}\right)$, and lower than that of cashew (124 mg $\left.100 \mathrm{~g}^{-1}\right)$ (TACO, 2011). Magnesium levels (5.65 mg $100 \mathrm{~g}^{-1}$ ), in turn, were similar to those of traditional fruits, including 'Aurora' peach (4 mg $\left.100 \mathrm{~g}^{-1}\right)$, plum, 'Argentina' apple, and 'Itália' grape (5 mg $\left.100 \mathrm{~g}^{-1}\right)$ (TACO, 2011). Regarding phosphorus, uvaia $\left(10.85 \mathrm{mg} 100 \mathrm{~g}^{-1}\right)$ presented similar contents to acerola (9 mg $\left.100 \mathrm{~g}^{-1}\right)$, carambola and papaya (11 mg $100 \mathrm{~g}^{-1}$ ), and apple (9-11 mg $100 \mathrm{~g}^{-1}$ ) (TACO, 2011). Calcium contents were similar to those reported by Sartori et al. (2010) for the same fruit $(10 \mathrm{mg} 100$ $\mathrm{g}^{-1}$ of pulp) and by Brazilian Food Composition Table (TACO, 2011) for jabuticaba, 'Tommy Atkins' mango, and watermelon ( $\left.8 \mathrm{mg} 100 \mathrm{~g} \mathrm{~g}^{-1}\right)$, as well as for 'Itália' grape (7 mg $\left.100 \mathrm{~g}^{-1}\right)$.

The contents of potentially toxic micronutrients (e.g., copper $\left.(\mathrm{Cu}) ; 0.95 \mathrm{mg} \mathrm{kg}^{-1}\right)$ are below the maximum tolerance threshold in food products allowed by the ongoing legislation: $10 \mathrm{mg} \mathrm{kg}^{-1}$ (BRASIL, 1998). This indicates the reliability of the in natura consumption as well as of the use in numerous preparations without the risk of intoxication. Manganese $(\mathrm{Mn})$ and zinc $(\mathrm{Zn})$ were

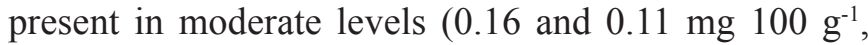
respectively).

Iron $(\mathrm{Fe})$ is a widely studied and one of the most cited microelements because of its essential character, which in turn is due to the role that it plays in hemoglobin, 
myoglobin, and cytochrome, besides being a component of several enzymatic systems and metabolic processes (SAINI et al., 2016). The recommended daily intake of $\mathrm{Fe}$ is approximately $10 \mathrm{mg}$ for men and $20 \mathrm{mg}$ for women (OMS, 1998). The iron contents found in $100 \mathrm{~g}$ of uvaia (3.38 mg) was shown to be promising among the 60 fruits compiled by Brazilian Food Composition Table (TACO, 2011), including açaí pulp (8.45 times greater). Our findings have also been reported by Pereira et al. (2014) for fruits from the same species at the Embrapa Temperate Agriculture experimental station in Pelotas, RS, Brazil.

Uvaia trees that produce large fruits present desirable characteristics for in natura commercialization, namely: higher pulp yield, fruit weight, and size. However, small fruits are firmer, sweeter, and richer in antioxidant compounds (total carotenoids, yellow flavonoids, and phenolic compounds) and may be considered for both in natura and processed consumptions.
As for mineral composition, uvaia stands out as an important source of nutrients. It can be used as a supplement to meet the daily requirements for minerals, particularly Fe as uvaia features higher iron contents that traditional fruits.

The authors thank the São Paulo Research Foundation (FAPESP) - grant \#2014/13473-7 (scholarship) and \#2014/12606-3 (research funding); the Coordination of Improvement of Higher Education Personnel (CAPES) (scholarship); the National Council for Scientific and Technological Development (CNPq) - process \#308521/2015-3 (research productivity grant) and 458123/2014-5 (research funding); and the grower Hugo Daibs, from Salesópolis, SP, Brazil, for providing the fruits.

Table 1. Physical and chemical characteristics of two uvaia (Eugenia pyriformis Cambess) populations harvested in Salesópolis, SP, Brazil.

\begin{tabular}{|c|c|c|c|}
\hline \multirow{2}{*}{ Variable } & \multicolumn{2}{|c|}{ Uvaia type (populations) } & \multirow{2}{*}{ C.V. $(\%)$} \\
\hline & large fruits & small fruits & \\
\hline Chromaticity (C) & 47.71 & 53.63 & 6.01 \\
\hline Whole fruit weight (g) & 22.00 & 8.25 & 11.05 \\
\hline Seeds $(\%)$ & 5.53 & 12.55 & 9.50 \\
\hline Pulp yield (\%) & 94.47 & 87.45 & 0.94 \\
\hline Longitudinal diameter (LD) (cm) & 3.08 & 2.00 & 8.03 \\
\hline Transverse diameter (TD) (cm) & 3.92 & 2.75 & 11.38 \\
\hline Firmness $\left(\mathrm{gf} \mathrm{cm}^{-2}\right)$ & 81.98 & 151.62 & 47.49 \\
\hline $\mathrm{pH}$ & 3.06 & 2.96 & 3.59 \\
\hline Total soluble solids (TSS) ( ${ }^{\circ}$ Brix) & 7.75 & 10.50 & 5.92 \\
\hline Total titratable acidity (TTA) (\% citric acid) & 1.63 & 1.67 & 4.49 \\
\hline TSS/TTA ratio & 4.85 & 6.14 & 7.08 \\
\hline Total soluble sugars (g glucose $100 \mathrm{~g}^{-1}$ ) & 4.41 & 5.61 & 3.88 \\
\hline Soluble pectins (\% galacturonic acid $100 \mathrm{~g}^{-1}$ pulp) & 0.17 & 0.18 & 7.50 \\
\hline Total pectins (\% galacturonic acid $100 \mathrm{~g}^{-1}$ pulp) & 0.95 & 0.95 & 5.56 \\
\hline
\end{tabular}


Table 2. Bioactive compounds of two uvaia (Eugenia pyriformis Cambess) populations harvested in Salesópolis, SP, Brazil.

\begin{tabular}{|c|c|c|c|}
\hline \multirow[t]{2}{*}{ Variable } & \multicolumn{2}{|c|}{ Uvaia type (populations) } & \multirow[b]{2}{*}{ C.V. $(\%)$} \\
\hline & large fruits & small fruits & \\
\hline Total carotenoids $\left(\mu \mathrm{g} \mathrm{g}^{-1}\right)$ & 20.7 & 25.6 & 12.60 \\
\hline Yellow flavonoids (mg $100 \mathrm{~g}^{-1}$ ) & 7.30 & 10.29 & 9.27 \\
\hline Total phenolic compounds (mg GAE 100 g-1) ${ }^{1}$ & 402.69 & 483.25 & 0.43 \\
\hline Ascorbic acid content (mg $\left.100 \mathrm{~g}^{-1}\right)$ & 110.51 & 122.51 & 6.25 \\
\hline $\begin{array}{l}\text { Antioxidant capacity - ORAC assay } \\
\text { (mmol Trolox } 100 \mathrm{~g}^{-1} \text { lyophilized pulp) }\end{array}$ & 13.79 & 17.09 & 9.74 \\
\hline $\begin{array}{l}\text { Antioxidant capacity - DPPH assay } \\
\text { (mmol Trolox } 100 \mathrm{~g}^{-1} \text { lyophilized pulp) }\end{array}$ & 16.77 & 17.84 & 4.34 \\
\hline
\end{tabular}

${ }^{1} \mathrm{GAE}$ : gallic acid equivalent.

Table 3. Contents of inorganic elements in whole uvaia (Eugenia pyriformis Cambess) fruits (peel + pulp), reported as $\mathrm{m} \mathrm{kg}^{-1}$, and contribution per fresh fruit, reported as $\mathrm{mg}$.

\begin{tabular}{lcc}
\hline Mineral & Average & $\begin{array}{c}\text { mg/fruit } \\
\text { (Average fruit weight=12.48 g) }\end{array}$ \\
\hline $\mathrm{P}$ & $108.47 \pm 6.48$ & 1.35 \\
$\mathrm{~K}$ & $991.45 \pm 127.44$ & 12.37 \\
$\mathrm{Ca}$ & $75.97 \pm 8.10$ & 0.95 \\
$\mathrm{Mg}$ & $56.53 \pm 6.12$ & 0.71 \\
$\mathrm{Cu}$ & $0.95 \pm 0.28$ & 0.01 \\
$\mathrm{Fe}$ & $33.83 \pm 21.20$ & 0.42 \\
$\mathrm{Mn}$ & $1.59 \pm 0.14$ & 0.02 \\
$\mathrm{Zn}$ & $1.15 \pm 0.21$ & 0.01 \\
\hline
\end{tabular}

\section{References}

AOAC - Association of Official Analytical Chemists. Official methods of analysis of AOAC international. $19^{\text {th }}$ ed. Gaithersburg: AOAC International, 2012. 3000 p.

BITTER, T.; MUIR, H.M. A modified uronic acid carbazole reaction.Analytical Biochemistry, New York, v.4, n.4, p.330-334, 1962.

BRASIL. Portaria $n^{\circ}$ 685, de 27 de agosto de 1995, da Agência Nacional de Vigilância Sanitária (ANVISA). Princípios gerais para o estabelecimento de níveis máximos de contaminantes químicos em alimentos. Diário Oficial da União, Brasília, DF, 24 de set. 1998. Seção 1, nº 183E, p. 03.
CALBO, A. G.; NERY, A. A. Medida de firmeza em hortaliças pela técnica de aplanação. Horticultura Brasileira, Brasília, DF, v.13, n.1, p.14-18, 1995.

CAVALINI, F. C.; JACOMINO, A. P.; TREVISAN, M. J.; MIGUEL, A. C. A. Ponto de colheita e qualidade de goiabas 'Kumagai' e 'Paluma'. Revista Brasileira de Fruticultura, Jaboticabal, v.37, n.1, p.64-72, 2015.

D'EVOLI, L.; MOSCATELLO, S.; BALDICCHI, A.; LUCARINI, M.; CRUZ-CASTILLO, J.G.; AGUZZI, A.; GABRIELLI, P.; PROIETTI, S.; BATTISTELLI, A.; FAMIANI, F.; BÖHM, V.; LOMBARDI-BOCCIA, G. Post-harvest quality, phytochemicals and antioxidant activity in organic and conventional kiwifruit (Actinidia deliciosa, cv.Hayward). Italian Journal of Food Science, Pinerolo, v.25, n.3, p.362-368, 2013. 
DUBOIS, M.; GILLES, K.A.; HAMILTON, J.K.; REBERS, P.; SMITH, F. Colorimetric method for determination of sugar and related substances. Analytical Chemistry, Washington, v.28, n.3, p.350-356, 1956.

FRANCIS, F.J.Analysis of anthocyanins. In: MARKAKIS, P. (Ed.). Anthocyanins as food colors. New York: Academic Press, 1982. p.181-207.

GARRIDO, J.I.; LOZANO, J.E.; GENOVESE, D.B. Effect of formulation variables on rheology, texture, colour, and acceptability of apple jelly: Modelling and optimization. LWT-Food Science and Technology, Amsterdam, v.62, n.1, p.325-332, 2015.

HAMZA, A.M.; COLLINS, A.; ADO, S.G.; IKUENOBE, C.E.; ATAGA, C.D.; ODEWALE, J.O. Proximate compositions evaluation and variability among cultivars of date palm (Phoenix dactylifera L.) in Nigeria. International Journal of Plant and Soil Science, Berlin, v.3, n.3, p.248-259, 2014.

KAULMANN, A.; BOHN, T. Carotenoids, inflammation, and oxidative stress - implications of cellular signaling pathways and relation to chronic disease prevention. Nutrition Research, New York, v.34, n.11, p.907-929, 2014.

LICHTENTHALER, H.K. Chorophylls and carotenoids: pigments of photosynthetic biomembranes. In: PACKER, L.; DOUCE, R. (Ed.). Methods in enzymology. London: Academic Press, 1987. v.148, p.350-81.

LIMA, J.S.S.; CASTRO, J.M.C.; SABINO, L.B.S.; LIMA, A.C.S.; TORRES, L.B.V. Physicochemical properties of Gabiroba (campomanesia lineatifolia) and Myrtle (blepharocalyx salicifolius) Native to the mountainous region of Ibiapaba-CE, Brazil. Revista Caatinga, Mossóro, v.29, n.3, p.753-757, 2016.

MALAVOLTA, E.; VITTI, G.C.; OLIVEIRA, S.A. de. Avaliação do estado nutricional das plantas: princípios e aplicações. 2.ed. Piracicaba: POTAFOS, 1997. 319p.

McCREADY, R.M.; McCOMB, E.A. Extraction and determination of total pectic materials in fruits. Analytical Chemistry, Washington, v.24, n.12, p.1586-1588, 1952.

MELO, P.S.; MASSARIOLI, A.P.; DENNY, C.; SANTOS, L.F.; FRANCHIN, M.; PEREIRA, G.E.; VIEIRA, T.M.F.S.; ROSALEN, P.L.; ALENCAR, S.M. Winery byproducts: extraction optimization, phenolic composition and cytotoxic evaluation to act as a new source of scavenging of reactive oxygen species. Food Chemistry, Barking, v.181, p.160-169, 2015.
OLIVEIRA, E.N.A.; COSTA SANTOS, D. da.; SOUSA, F. C. de.; MARTINS, J. N.; OLIVEIRA, S. P.A. de. Obtenção de ubaia desidratada pelo processo de liofilização. Revista Brasileira de Tecnologia Agroindustrial, Ponta Grossa, v.4, n.2, p.235-242, 2010.

OMS - Organização Mundial da Saúde. Necessidades de energia e proteínas. São Paulo: Roca, 1998. 225p.

PEREIRA, M.C.; BOSCHETTI, W.; RAMPAZZO, R.; CELSO, P.G.; HERTZ, P.F.; RIOS, A.D.O.;VIZOTTO, M.; FLORES, S.H. Mineral characterization of native fruits from the southern region of Brazil. Food Science Technology, Campinas, v.34, n.2, p.258-266, 2014.

REIS, R.C.; VIANA, E.S.; JESUS, J.L.; DANTAS, J.L.L.; LUCENA, R.S. Caracterização físico-química de frutos de novos híbridos e linhagens de mamoeiro. Pesquisa Agropecuária Brasileira, Brasília, DF, v.50, n.3, p.210$217,2015$.

RUFINO, M.S.M.; ALVES, R.E.; BRITO, E.S.; SILVEIRA, M.R.S.; MOURA, C.F.H. Quality for fresh consumption and processing of some non-traditional tropical fruits from Brazil. Fruits, Paris, v.64, p.361-370, 2009.

RUFINO, M.S.R.; ALVES, R.E.; BRITO, E.S.; PÉREZJIMÉNEZ, J.; SAURA-CALIXTO, F.; MANCINIFILHO, J. Bioactive compounds and antioxidant capacities of 18 non-traditional tropical fruits from Brazil. Food Chemistry, Barking, v.121, n.4, p.996-1002, 2010.

\section{S.O.S. MATA ATLÂNTICA. Atlas dos remancescentes} florestais da Mata Atlântica período 2013-2014. Disponível em: $<$ https://www.sosma.org.br/nossa-causa/amata-atlantica/>. Acesso em: 28 out. 2016.

SAINI, R.K.; NILE, S.H.; KEUM, Y-S. Food science and technology for management of iron deficiency in humans: A review. Trends in Food Science \& Technology, Kidlington, v.53, p.13-22, 2016.

SANTOS, C. H. B., CRUZ NETO, A. J.; JUNGHANS, T. G., JESUS, O. N.; GIRARDI, E. A. Estádio de maturação de frutos e influência de ácido giberélico na emergência e crescimento de Passiflora spp. Revista Ciência Agronômica, Fortaleza, v.47, n.3, p.481-490, 2016.

SARTORI, S.; DONADIO, L.C.; MARTINS, A.B.G.; MORO, F.V. Uvaia. Jaboticabal: Funep, 2010. 32p.

SCALON, S.P.Q.; DELL'OLIO, P.; FORNASIERI, J.L. Temperatura e embalagens na conservação pós-colheita de Eugenia uvalha Cambess - Mirtaceae. Ciência Rural, Santa Maria, v.34, n.6, p.1965-1968, 2004. 
SOETHE, C.; STEFFENS, C. A.; AMARANTE, C. V.T.; MARTIN, M. S.; BORTOLINI, A. J. Qualidade, compostos fenólicos e atividade antioxidante de amoras-pretas 'Tupy' e 'Guarani' armazenadas a diferentes temperaturas. Pesquisa Agropecuária Brasileira, Brasília, DF, v.51, n.8, p.950-957, 2016.

STROHECKER, R.; HENNING, H. M. Análisis de vitaminas: métodos comprobados. Madrid: Paz Montalvo, 1967. 428p.

TACO. Tabela brasileira de composição de alimentos. 4.ed. Campinas: NEPA-UNICAMP, 2011.161p. Disponível em: $\leq$ http://www.unicamp.br/nepa/taco/contar/taco 4 edicao_ampliada_e revisada.pdf?arquivo $=$ taco 4 versao ampliada e revisada.pdf $>$. Acesso em: 10 out. 2016.
TIVERON, A.P.; MELO, P.S.; BERGAMASCHI, K.B.; VIEIRA, T.M.F.S.; REGITANO-D'ARCE, M.A.B.; ALENCAR, S.M. Antioxidant activity of Brazilian vegetables and its relation with phenolic composition. International Journal of Molecular Sciences, Basel, v.13, n.7, p.8943-8957, 2012.

WOISKY, R.G.; SALATINO, A. Analysis of propolis: some parameters and procedure for chemical quality control. Journal of Apicultural Research, Cardiff, v.37, n.2, p.99-105, 1998.

ZILLO, R. R.; SILVA, P.P.M. da.; ZANATTA, S.; DO CARMO, L. F.; SPOTO, M. H. Qualidade físico-química da fruta in natura e da polpa de uvaia congelada. Revista Brasileira de Produtos Agroindustriais, Campina Grande, v.15, n.3, p.293-298, 2013.

\section{ERRATUM}

http://dx.doi.org/10.1590/0100-29452018511erratum

Erratum of article: Silva, A. P. G. da, Tokairini, T. de O., Alencar, S. M., \& Jacomino, A. P. Characteristics of the fruits of two uvaia populations grown in Salesópolis-SP, Brazil. Rev. Bras. Frutic., 40(2), e-511. http://dx.doi.10.1590/0100-29452018511

In the page 1, Authors' affiliations - footnote

where it reads:

Tatiane de Oliveira TokairinI ${ }^{1}$, should read:

Tatiane de Oliveira Tokairin ${ }^{1}$

\section{where it reads:}

${ }^{1}$ Universidade de São Paulo. Departartamento de Ciências Agrárias. Piracicaba-SP. E-mails: alinepgsilva@gmail.com, tatianetokairin@hotmail.com; jacomino@usp.br

${ }^{2}$ Universidade de São Paulo. Departartamento de Ciências Agrárias. Piracicaba-SP. E-mail: smalencar@usp.br.

\section{should read:}

'University of São Paulo, "Luiz de Queiroz" College of Agriculture, Crop Science Departament, Postharvest Laboratory of Horticultural Products, Piracicaba, SP, Av. Pádua Dias 11, CEP 13418-900. E-mail addresses: alinepgsilva@gmail.com, tatianetokairin@ hotmail.com; jacomino@usp.br ;

${ }^{2}$ University of São Paulo, "Luiz de Queiroz" College of Agriculture, Department of Agri-Food Industry, Food and Nutrition, Piracicaba, SP, Av. Pádua Dias, 11, CEP 13418-900. E-mail: smalencar@usp.br. 